\title{
Korelasi antara Minat Baca dengan Kemampuan Menulis Teks Prosedur Kompleks pada Siswa Kelas VII SMP Negeri Sumber Rejo Kabupaten Musi Rawas
}

\author{
Supini Riyanti, Susetyo, Dian Eka Chandra Wardhana \\ Program Magister Pendidikan Bahasa Indonesia, Universitas Bengkulu \\ Corresponding email: riyantisupini@gmail.com
}

\begin{abstract}
The purpose of this study was to determine whether there is a positive and significant correlation between interest in reading with the ability to write complex procedure texts in Indonesian subjects in Grade VII students of SMP Negeri Sumber Rejo, Musi Rawas Regency. The research method uses a simple correlation method. Data collection techniques using questionnaires and tests. The population in this study was 81 students, sampling from the entire population divided by the number of students multiplied by the prediction set at $10 \%$, then obtained 45 students. Analysis of the data used is the Pearson Product Moment Test. The results showed that there was a positive and significant relationship between interest in reading with the ability to write procedural texts in Grade VII students of SMP Negeri Sumber Rejo, Musi Rawas Regency. This is evidenced by the correlation coefficient of 0.01 smaller than 0.05 at a significant level of $5 \%$. This proves that at a significant level $\alpha=0.05$ or at the level of confidence of $95 \%$ there is a significant relationship between interest in reading and the ability to write complex procedural texts in SMP Negeri Sumber Rejo, Musi Rawas Regency.
\end{abstract}

Keywords: Correlation, Interest in Reading, Writing Complex Procedure Texts, Indonesian

\begin{abstract}
Abstrak
Penelitian ini bertujuan untuk mengetahui ada tidaknya korelasi yang positif dan signifikan antara minat baca dengan kemampuan menulis teks prosedur kompleks pada mata pelajaran Bahasa Indonesia siswa kelas VII SMP Negeri Sumber Rejo, Kabupaten Musi Rawas. Metode penelitian menggunakan metode korelasi sederhana. Teknik pengumpulan data menggunakan teknik angket dan tes. Populasi dalam penelitian ini sebanyak 81 siswa, pengambilan sampel dari seluruh populasi dibagi jumlah siswa dikali dengan prediksi yang ditetapkan $10 \%$, maka diperoleh 45 siswa. Analisis data yang digunakan adalah dengan $U j i$ Pearson Product Moment. Hasil penelitian menunjukkan bahwa terdapat hubungan yang positif dan signifikan antara minat baca dengan kemampuan menulis teks prosedur pada siswa kelas VII SMP Negeri Sumber Rejo Kabupaten Musi Rawas. Hal ini dibuktikan dengan koefisien korelasi sebesar 0,01 lebih kecil dari 0,05 pada taraf signifikan $5 \%$. Hal ini membuktikan bahwa pada taraf signifikan $\alpha=0,05$ atau pada taraf kepercayaan $95 \%$ terdapat hubungan yang
\end{abstract}


Korelasi antara Minat Baca dengan Kemampuan Menulis Teks Prosedur ...

signifikan antara minat baca dan kemampuan menulis teks prosedur kompleks pada SMP Negeri Sumber Rejo Kabupaten Musi Rawas.

Kata kunci: Korelasi, Minat Baca, Menulis Teks Prosedur Kompleks, Bahasa Indonesia

\section{PENDAHULUAN}

Aktivitas menulis merupakan bentuk manifestasi kompetensi berbahasa paling akhir dikuasai pembelajar bahasa setelah kompetensi mendengarkan, berbicara, dan membaca. Dibandingkan dengan tiga komponen berbahasa yang lain, kompetensi menulis secara umum dapat dikatakan lebih sulit dikuasai (Nurgiyantoro, 2012:423). Menulis merupakan proses berkomunikasi untuk mengungkapkan pikiran, gagasan, perasaan, dan kehendak kepada orang lain secara tertulis. Dengan menulis seseorang dapat mengungkapkan pikiran dan gagasan untuk mencapai maksud dan tujuan. Hasil dari kegiatan menulis adalah tulisan atau karangan (Muslikhah, dalam Susetyo, 2010:49). Keterampilan menulis juga merupakan keterampilan berbahasa yang bersifat produktif dengan cara menuangkan gagasan ke dalam wacana tertulis atau representasi grafis sehingga memberikan pemahaman yang komprehensif kepada pembaca tentang pesan yang disampaikan (Noermanzah, 2018:116).

Dari pengertian di atas dapat disimpulkan bahwa menulis merupakan salah satu keterampilan berbahasa dalam menuangkan gagasan secara tertulis yang bersifat produktif sehingga menuntut adanya latihan dan membutuhkan ketelitian serta kecerdasan. Salah satunya adalah untuk menuangkan ide dalam bentuk tulisan atau lambang-lambang kepada orang lain untuk mencapai maksud atau tujuan. Berkaitan dengan pengertian menulis di atas, terutama pada mata pelajaran Bahasa Indonesia bertujuan agar para siswa memiliki kompetensi berbahasa Indonesia. Hal ini sesuai dengan kurikulum 2013 pembelajaran bahasa sangat penting untuk diajarkan di sekolah-sekolah. Dari berbagai fungsi kegiatan diharapkan dapat membantu siswa mengembangkan kompetensi berbahasa, kognisi, kepribadian, dan emosi siswa. Selain itu, pembelajaran bahasa Indonesia diharapkan dapat menumbuhkan minat baca dan minat menulis.

Bahasa Indonesia sebagai bahasa nasional harus lebih diarahkan pada kemampuan dan keterampilan siswa. Salah satunya untuk berkomunikasi secara lisan maupun tulis. Pembelajaran bahasa Indonesia diharapkan dapat meningkatkan keterampilan berbahasa siswa yang meliputi keterampilan mendengarkan, berbicara, membaca, dan menulis. Keempat keterampilan ini saling berkaitan dan saling melengkapi dalam kegiatan belajar mengajar.

Untuk mencapai tujuan tersebut, diperlukan minat siswa saat proses belajar. Dengan adanya minat maka menulis dan membaca siswa lebih termotivasi untuk mempelajarai sesuatu. Hal ini agar siswa lebih aktif dalam mengemukakan pendapat, bertanya, dan kreatif selama proses pembelajaran. Kondisi belajar tersebut secara tidak langsung dapat membantu siswa dalam mengembangkan keterampilan berbahasa mereka, khususnya dalam keterampilan menulis.

Dengan keterampilan membaca dan menulis seseorang akan dapat menguasai sebuah ilmu pengetahuan. Oleh karena itu, diharapkan adanya kemauan siswa untuk membaca. Dengan adanya minat atau kemauan baca, maka mempunyai pengaruh yang besar terhadap kebiasaan membaca. Kegiatan siswa dalam membaca tanpa mempunyai minat baca yang tinggi maka siswa tersebut tidak akan membaca dengan sepenuh hati. Apabila siswa tersebut membaca atas kemauan atau kehendaknya sendiri maka ia akan membaca dengan sepenuh hati. Apabila 
siswa sudah terbiasa dengan membaca, kebiasaan tersebut akan dilakukan secara terus-menerus. Selain itu, kegemaran membaca memberikan dampak yang positif untuk siswa tersebut. Jika minat baca tinggi maka minat belajarnya pun juga tinggi. Siswa yang senang membaca akan mempunyai pengetahuan yang luas dari buku yang dibacanya. Sangat disayangkan, apabila siswa tidak suka membaca atau mempunyai minat membaca yang rendah karena pengetahuan siswa akan sempit.

Minat baca siswa yang rendah membuat mutu pendidikan juga semakin menurun karena minat baca siswa berpengaruh terhadap mutu pendidikan. Rendahnya minat baca menyebabkan merosotnya kualitas lulusan siswa. Padahal dengan membaca, siswa menjadi tahu apa yang sebelumnya belum diketahui. Kemudian, secara umum untuk meningkatkan pengertian, pemahaman dan pengetahuan tentang pelajaran dalam menguasai informasi, dan perkembangan teknologi adalah dengan kegiatan membaca. Apabila siswa tersebut sudah malas untuk membaca maka hal tersebut juga berpengaruh terhadap prestasi belajar siswa tersebut. Jika minat baca tinggi maka mutu pendidikan juga tinggi sehingga kualitas sumber daya manusia juga meningkat. Untuk itu, membaca sebaiknya ditumbuhkan pada diri siswa sejak dini.

Sandjaja (2005), mengartikan minat baca adalah suatu perhatian yang kuat dan mendalam disertai dengan perasaan senang terhadap kegiatan membaca sehingga dapat mengarahkan seseorang untuk membaca dengan kemauannya sendiri. Minat membaca adalah sumber motivasi kuat bagi seseorang untuk menganalisa dan mengingat serta mengevaluasi bacaan yang telah dibacanya. Minat baca mempengaruhi bentuk serta intensitas seseorang dalam menentukan cita-citanya kelak di masa yang akan datang. Hal tersebut juga adalah bagian dari proses pengembangan diri yang harus senantiasa diasah sebab minat membaca tidak diperoleh dari lahir.

Semakin banyak membaca, semakin banyak pengetahuan dan informasi yang diperoleh. Somadayo (2011:45) menyatakan bahwa membaca adalah suatu kegiatan interaktif untuk memetik serta memahami arti atau makna yang terkandung di dalam bahan tulis. Banyak faktor yang mempengaruhi kemampuan siswa dalam membaca. Faktor tersebut terdiri atas faktor internal, yaitu faktor yang berasal dari dalam diri siswa, maupun faktor eksternal, yaitu faktor yang berasal dari luar diri siswa. Faktor internal antara lain ialah minat baca, penguasaan kosakata, bakat, prestasi belajar bahasa Indonesia, mental, motivasi, dan sebagainya (Soedarso, 1989:58-59). Faktor eksternal misalnya metode pembelajaran, guru, kelengkapan buku yang ada di sekolah, lingkungan, dan kurikulum. Faktor sosial budaya serta ekonomi keluarga juga berpengaruh terhadap kegiatan membaca siswa. Salah satu faktor yang mempengaruhi kemampuan siswa dalam membeca ialah minat baca.

Menurut Tampubolon (1993:41), minat ialah perpaduan keinginan dan kemauan yang dapat berkembang jika ada motivasi. Sedangkan membaca adalah suatu kegiatan fisik dan mental. Melalui membaca informasi dan pengetahuan yang berguna bagi kehidupan dapat diperoleh. Inilah motivasi pokok yang dapat mendorong tumbuhnya dan berkembangnya minat membaca. Apabila minat ini sudah tumbuh dan berkembang, dalam arti bahwa orang bersangkutan sudah mulai suka membaca, maka kebiasaan membaca pun akan berkembang. Orang yang mempunyai minat membaca yang kuat akan diwujudkannya dalam kesediaannya untuk mendapat bahan bacaan dan kemudian membacanya atas kesadarannya sendiri serta akan dituangkan dalam tulisan. 
Melalui kegiatan menulis teks, siswa dapat mengomunikasikan ide/gagasan serta pengalamannya. Siswa juga dapat meningkatkan dan memperluas pengetahuannya melalui tulisan-tulisan. Di samping itu, ada beberapa manfaat yang dapat diperoleh dari menulis yaitu dapat meningkatkan kecerdasan, dapat mengembangkan daya imajinasi, kreatif, dan mendorong kemauan untuk mengumpulkan informasi.

Pembelajaran bahasa Indonesia pada kurikulum 2013 berbasis teks (Permendikbud No. 64 tahun 2013). Siswa dituntut untuk mampu menghasilkan/menulis suatu teks setiap materi ajar bahasa Indonesia. Oleh karena itu, kemampuan dalam menulis harus dimiliki oleh siswa. Berdasarkan Permendiknas No. 24 Tahun 2016, bahasa Indonesia kelas VII membahas materi ajar, antara lain teks deskripsi, teks cerita fantasi, teks prosedur, teks hasil observasi, puisi rakyat, fabel, surat pribadi, surat dinas, dan literasi. Dalam penelitian ini, penulis mebatasi objek, yaitu menulis teks prosedur.

Berdasarkan hasil pengamatan dan wawancara kepada siswa, sebagian besar mengalami kesulitan dalam menulis teks prosedur. Hal ini dianggap suatu kegiatan yang sangat sulit. Mereka masih mengalami kesulitan dalam menyusun teks prosedur kompleks, misalnya menyusun kesesuain isi dengan judul, kurangnya minat dalam menulis, bahkan menulis dianggap sesuatu yang menjadi momok besar. Hambatan tersebut menjadikan hasil keterampilan menulis teks prosedur siswa masih belum mencapai nilai sesuai KKM sekolah. Guru bahasa Indonesia, menjelaskan bahwa beberapa hal yang menyebabkan keterampilan menulis siswa masih kurang, tidak lepas dari latar belakang siswa, yakni motivasi belajar siswa di kelas rendah, khususnya minat dalam pembelajaran menulis teks prosedur, dan siswa masih kurang memiliki motivasi yang kuat untuk berlatih menulis sehingga mengalami kesulitan dalam menyusun serta pemunculan ide sebuah teks yang runtut.

Dengan adanya minat baca yang tinggi diharapkan dan mempengaruhi siswa dalam menulis teks prosedur. Sesuai dengan ketentuan yang tertera pada kurikulum bahwa siswa dapat menulis teks prosedur dengan memperhatikan pilihan kata, kelengkapan struktur, dan kaidah penggunaan kata, kalimat/tanda baca/ejaan. Melihat kondisi seperti ini, peneliti ingin meneliti bagaimana tingkat kemampuan siswa dalam menulis tek prosedur. Hal itulah yang melatar belakangi peneliti untuk mengadakan penelitian ini. Dengan harapan dapat mengetahui minat baca siswa dalam menulis teks prosedur. Khususnya pada siswa kelas VII SMP Negeri Sumber Rejo Kecamatan Megang Sakti Kabupaten Musi Rawas.

Sesuai dengan Kurikulum 2013 yang terdapat dalam silabus, standar kompetensi yaitu menyajikan data, gagasan, kesan dalam bentuk teks deskripsi tentang objek (sekolah, tempat wisata, tempat bersejarah, dan atau suasana pentas seni daerah) secara tertulis dan lisan dengan memperhatikan struktur, kebahasaan baik lisan maupun tulis. Kemudian, tujuan pembelajaran mampu menulis teks deskripsi dengan memperhatikan pilihan kata, kelengkapan struktur, dan kaidah penggunaan kata, dan kalimat/tanda baca/ejaan.

Siswa SMP kelas VII mengungkapkan berbagai bentuk teks, salah satunya yaitu teks prosedur. Permasalahan dalam kemampuan menulis teks prosedur ini sangat berpengaruh dari tingkat minat baca. Berdasarkan hasil penelitian yang dilakukan oleh Fitri (2015) yang meneliti kontribusi minat baca dan penguasaan kosakata terhadap kemampuan membaca pemahaman di kelas X SMA 1 Padang Ganting. Penelitian yang dilakukan adalah penelitian deskripsif dengan pendekatan 
kuantitatif dan metode korelasional, berbeda dengan penelitian yang akan direncanakan yaitu variabel dependennya kemampuan menulis teks prosedur kompleks.

Rumusan masalah dalam penelitian ini yaitu "Adakah korelasi antara minat baca dengan kemampuan menulis teks prosedur kompleks siswa kelas VII SMP Negeri Sumber Rejo? Dengan harapan dapat dijadikan dasar dalam mengembangkan kemampuan menulis teks prosedur kompleks dengan mempertimbangkan minat baca siswa.

\section{METODE}

Metode penelitian yang digunakan yaitu metode korelasi antara minat baca dengan menulis teks prosedur kompleks. Data yang diperoleh dalam penelitian ini berupa hasil pengukuran terhadap dua variabel yang diteliti dan dikumpulkan melalui angket dan tes tertulis. Variabel bebas pertama, yaitu minat baca, yang diteliti dan dikumpulkan melalui angket dan variabel terikat, yaitu kemampuan menulis teks prosedur diteliti dan dikumpulkan melalui tes tertulis. Data untuk variabel minat baca adalah skor hasil pengisian angket minat baca. Selanjutnya, data variabel keterampilan menulis teks prosedur adalah skor hasil tes keterampilan menulis teks prosedur.

Teknik pengumpulan data menggunakan angket dan tes. Angket digunakan untuk mengukur minat baca, sedangkan tes untuk mengukur kemampuan menulis teks prosedur kompleks. Tes yang digunakan adalah tes unjuk kerja. Tes tersebut diberikan kepada siswa untuk mengukur tingkat kemampuan menulis teks prosedur siswa kelas VII SMP Negeri Sumber Rejo. Hasil tes menulis teks prosedur akan dinilai dengan mengacu pada rubrik pembangun kemampuan menulis teks prosedur, yaitu isi, aspek struktur teks prosedur, aspek kaidah penulisan kalimat, dan ciri kebahasaan. Instrumen dalam penelitian ini terdiri dari dua kuesioner, yaitu instrumen minat baca dan tes unjuk kerja (menulis teks prosedur). Instrumen minat baca digunakan untuk mengetahui minat baca siswa dan tes unjuk kerja digunakan untuk mengetahui hasil kemampuan menulis teks prosedur.

Populasi dalam penelitian ini yaitu siswa kelas VII SMP Negeri Sumber Rejo yang berjumlah 81 siswa. Sampel dalam penelitian ini adalah sebagian yang mewakili populasi. Dalam penelitian ini sampel diambil sebanyak 45 orang dari populasi yaitu berjumlah 81 orang. Untuk uji coba instrumen sebanyak 45 orang. Dengan demikian, untuk memperoleh populasi dan sampel yaitu jumlah seluruh sampel dibagi jumlah siswa dikali dengan presisi yang ditetapkan 10\%. Teknik analisis data menggunakan uji korelasi Product Moment untuk melihat ada tidaknya hubungan yang positif antara minat baca dengan kemampuan menulis teks prosedur kompleks siswa. Sebelum uji korelasi, dihitung dulu tingkat homogenitas dan normalitas datanya. Apabila data homogen dan normalitas maka dilakukan uji parametrik dengan uji korelasi Product Moment.

\section{HASIL}

\section{Minat Baca}

Dari data hasil kuesioner minat baca dari 45 siswa sampel dengan 30 soal diperoleh jumlah jawaban tertingi 96 dengan nilai 80, jumlah jawaban terendah 80 dengan nilai 66,67. Sedangkan rata-rata berjumlah 86,54 atau 72,13. Dari hasil tersebut dapat disimpulkan bahwa tingkat keberminatan anak terhadap buku atau 
bacaan dapat dikatakan berminat. Nampak pada skor tertinggi 96 (80) dan terendah adalah $80(66,67)$ dengan rata-rata yang diperoleh 72,13.

Kemudian, berdasarkan tabel distribusi frekuensi di atas dapat digambarkan bahwa dari 45 siswa sampel nilai instrumen angket di kelas VII SMP Negeri Sumber Rejo tertinggi mencapai 80 (2,22\%), dan nilai terendah 66,66 (6,66\%). Dengan kriteria validias tinggi karena berada pada kriteria antara $0,61<r \leq 0,80$.

\section{Kemampuan Menulis Teks Prosedur Kompleks}

Hasil perolehan skor kemampuan menulis teks prosedur kompleks pada siswa sampel tersebut dari 45 siswa sampel diperoleh skor tertinggi dengan skor 29 nilai 90,6 berjumlah satu siswa, skor 28 rata-rata 14 berjumlah 7 orang dengan nilai 87,5 , skor 26 rata-rata 13 berjumlah 11 orang dengan nilai 81,25 , skor 24 rata-rata 12 berjumlah 14 orang dengan nilai 75, skor 23 rata-rata 11,5 berjumlah 2 orang dengan nilai 71,87, skor 22 rata-rata 11 berjumlah 2 orang dengan nilai 68,75, skor 20 rata-rata 10 berjumlah 2 orang dengan nilai 62,5, skor 18 dengan rata-rata 9 berjumlah 3 orang dengan nilai 56,25, skor 16 rata-rata 6 berjumlah 2 orang dengan nilai 50. Secara tidak langsung menunjukkan tingkat kemampuan siswa dalam menulis teks prosedur. Variasi perolehan skor pada tabel 9 di atas mengindentifikasi variasi tingkat kemampuan menulis prosedur siswa kelas VII SMP Negeri Sumber Rejo Kabupaten Musi Rawas. Berdasarkan hasil analisis kemampuan menulis teks prosedur kompleks menunjukkan bahwa dari 45 siswa yang dijadikan sampel penelitian pada pembelajaran menulis teks prosedur kelas VII memperoleh nilai ratarata 75,69 dengan kategori mampu.

\section{Hasil Uji Homogenitas}

Hasil uji homogenitas menggunakan menggunakan SPSS 20. Tujuan uji homogenitas ini untuk mengetahui kelompok data yang diteliti mempunyai varians yang homogen atau tidak. Berikut hasil uji homogenitas menggunakan SPSS 20.

Tabel 1. Hasil Uji Homogenitas

ANOVA
\begin{tabular}{|l|r|r|r|r|r|}
\hline & \multicolumn{1}{|c|}{ Denulis } \\
\hline Between Groups & Sum of Squares & Df & Mean Square & F & Sig. \\
Within Groups & 280.900 & 1 & 280.900 & 4.653 & .034 \\
Total & 5312.089 & 88 & 60.365 & & \\
\hline
\end{tabular}

Uji homogenitas dilakukan untuk memperoleh data minat baca dengan nilai menulis teks prosedur kompleks. Hasil uji homogenitas dengan menggunakan SPSS 20, diperoleh nilai probabilitas (sig) 0,34 lebih besar dari $\underset{\leftarrow}{\alpha=0,05}$ berarti $H_{0}$ diterima. Hasil uji pada tabel di atas menunjukkan $\alpha=0,34$ bahwa data hasil uji homogenitas varians data hasil belajar siswa adalah homogen.

\section{Hasil Uji Normalitas}

Uji normalitas data sebagai persyaratan utama untuk uji parametrik. Uji normalitas data dalam penelitian ini menggunakan Uji Kolmogorov Smirnov dengan bantuan SPSS 20. Hasil dari Uji Kolmogorov Smirnov menunjukkan bahwa nilai Sig. sebesar 0,00 >0,05. Maka, dapat dikatakan bahwa data penelitian berdistribusi 
normal. Berikut hasil dari perhitungan uji normalitas data dengan Uji Kolmogorov Smirnov dengan bantuan SPSS 20.

Tabel 2. Hasil Uji Normalitas Data Penelitian

\begin{tabular}{|ll|r|}
\hline \multicolumn{2}{|c|}{ One-Sample Kolmogorov-Smirnov Test } \\
\hline $\mathrm{N}$ & \multicolumn{1}{|c|}{ Menulis } \\
Normal Parameters ${ }^{\mathrm{a}, \mathrm{b}}$ & Mean & 45 \\
& Std. Deviation & 75.4667 \\
Most Extreme Differences & Absolute & .13455 \\
& Positive & .105 \\
& Negative & -.237 \\
Test Statistic & .237 \\
Asymp. Sig. (2-tailed) & $.000^{c}$ \\
\hline a. Test distribution is Normal. \\
b. Calculated from data. \\
c. Lilliefors Significance Correction.
\end{tabular}

\section{Hasil Uji Korelasi}

Dari hasil uji korelasi Product Moment menggunakan SPSS 20 diperoleh informasi bahwa koefisien korelasi pada sebesar 0,01 lebih kecil dari 0,05 pada taraf signifikan 5\%, jadi Ha diterima. Hal ini membuktikan bahwa pada taraf signifikan $\alpha=$ 0,05 atau pada taraf kepercayaan 95\% terdapat hubungan yang signifikan antara minat baca dan kemampuan menulis teks prosedur kompleks pada SMP Negeri Sumber Rejo Kabupaten Musi Rawas. Hal ini dapat dilihat pada tabel hasil korelasi SPSS 20 berikut.

\section{Tabel 3. Hasil Uji Korelasi}

One-Sample Test

\begin{tabular}{|c|c|c|c|c|c|c|}
\hline & \multicolumn{6}{|c|}{ Test Value $=70$} \\
\hline & \multirow[b]{2}{*}{$\mathrm{T}$} & \multirow[b]{2}{*}{ df } & \multirow[b]{2}{*}{ Sig. (2-tailed) } & \multirow[b]{2}{*}{ Mean Difference } & \multicolumn{2}{|c|}{$\begin{array}{l}\text { 95\% Confidence Interval of the } \\
\text { Difference }\end{array}$} \\
\hline & & & & & Lower & Upper \\
\hline $\begin{array}{l}\text { Minat } \\
\text { Menulis }\end{array}$ & $\begin{array}{l}3.536 \\
3.634\end{array}$ & $\begin{array}{l}44 \\
44\end{array}$ & $\begin{array}{l}.001 \\
.001\end{array}$ & \begin{tabular}{|l}
2.04444 \\
5.55556
\end{tabular} & $\begin{array}{r}.8792 \\
2.4747\end{array}$ & $\begin{array}{l}3.2097 \\
8.6364\end{array}$ \\
\hline
\end{tabular}

\section{PEMBAHASAN}

Data minat baca siswa Kelas VII SMP Negeri Sumber Rejo diperoleh dari angket minat baca terdiri atas 30 butir pernyataan dengan rentangan skor 1 - 4 . Skor maksimal yang bisa diperoleh siswa adalah 96 dan skor minimal adalah 80 . Data variabel minat baca diperoleh dari nilai setiap siswa. Berdasarkan hasil analisis data, diperoleh nilai tertinggi 80 , nilai terendah 66,67 , nilai rata-rata sebesar 72,13 . Dari tabel interval persentase skala 10, nilai angket minat baca siswa kelas VII SMP Negeri Sumber Rejo tergolong lebih dari cukup atau tinggi yang berada pada rentangan $66-75 \%$. Hasil angket minat baca membuktikan bawa minat baca memiliki hubungan yang signifikan dengan kemampuan menulis teks prosedur siswa. Hubungan minat baca dengan kemampuan menulis teks prosedur siswa saling berkaitan, karena dengan minat baca yang tinggi maka dalam menulis juga akan baik. 
Hal ini juga ditunjukkan dengan rata-rata minat baca yaitu 72,13 sedangkan menulis teks prosedur rata-ratanya yaitu 75,69 pada Kelas VII SMP Negeri Sumber Rejo Kabupaten Musi Rawas. Kemudian, hal ini dibuktikan dengan koefisien korelasi pada sebesar 0,01 lebih kecil dari 0,05 pada taraf signifikan 5\%, jadi Ha diterima. Hal ini membuktikan bahwa pada taraf signifikan $\alpha=0,05$ atau pada taraf kepercayaan $95 \%$ terdapat hubungan yang signifikan antara minat baca dan kemampuan menulis teks prosedur kompleks pada SMP Negeri Sumber Rejo Kabupaten Musi Rawas. Hal ini sesuai dengan pendapat Rustam (2015:86) bahwa apabila nilai Sig kriteria pengujian yang digunakan lebih kecil dari nilai 0.05 , maka terdapat hubungan yang signifikan variabel independent yang diujicobakan.

Minat baca pada kelas VII SMP Negeri Sumber Rejo terdapat hubungan terhadap kemampuan menulis teks prosedur. Hal ini dapat dibuktikan dari hasil nilai yang diperoleh siswa dan ketika proses pembelajaran yaitu antusias siswa sangat tinggi terutama saat pembelajaran berlangsung. Dengan minat baca yang tinggi maka memberikan hubungan yang posistif terhadap kemampuan siswa dalam menulis teks prosedur.

Hasil penelitian minat baca siswa sangat berhubungan dengan kemampuan menulis teks prosedur siswa SMP Negeri Sumber Rejo Kabupaten Musi Rawas, membuktikan bahwa penelitian sebelumnya yang sudah dilakukan oleh Fitri (2015:128) yang khusus meneliti kontribusi minat baca dan penguasaan kosakata terhadap kemampuan membaca pemahaman siswa kelas X SMA Negeri 1 Padang Ganting Kabupaten Tanah Datar. Penelitian yang dilakukan adalah penelitian kuantitatif dan metode korelasi. Hasil penelitiannya menunjukkan bahwa (1) minat baca berkontribusi signifikan terhadap keterampilan pemahaman bacaan; (2) penguasaan kosakata berpengaruh signifikan terhadap membaca keterampilan pemahaman; dan (3) minat baca dan penguasaan kosakata bersama-sama memberikan kontribusi signifikan terhadap kemampuan membaca pemahaman. Dapat disimpulkan bahwa semakin tinggi minat membaca dan penguasaan kosakata siswa maka lebih tinggi pemahaman membaca siswa.

Hal ini didasari dari penelitian yang dilakukan oleh Rusmini (2018) yaitu, Kemampuan Menulis Teks Prosedur Siswa Kelas VIII SMP Negeri 1 Kabupaten Pangkap. Hasil penelitian ini menunjukkan bahwa siswa kelas VIII SMP Negeri 1 memperoleh nilai 80,54 dengan persentase $77,41 \%$ yaitu mampu menulis teks prosedur. Pada aspek ini, nilai rata-rata siswa sampel baerada dalam kategori mampu dengan nilai 86,29. Pada aspek struktur, nilai rata-rata siswa sampel berada dalam kategori mampu dengan nilai 85,48 . Pada aspek kaidah penulisan nilai ratarata siswa sampel berada dalam kategori cukup dengan nilai 73,79, dan pada aspek ciri kebahasaan, nilai rata-rata siswa sampel berada dalam kategori cukup dengan nilai 77,01 .

Hasil menulis teks prosedur yang ditulis oleh siswa sebagian besar sudah menunjukkan kemampuan siswa dalam menulis teks prosedur yaitu sesuai dengan kriteria penulisan teks prosedur dilihat dari aspek isi, aspek struktur, aspek kaidah penulisan, dan aspek ciri kebahasaan. Hal ini sesuai dengan pendapat Mahsun (2014:30) bahwa teks adalah teks yang bertujuan untuk memberikan pengarahan atau tentang langkah-langkah sesuatu yang telah ditentukan. Teks berisikan suatu pengamatan, ataupun percobaan, teks juga memiliki struktur berpikir, judul, tujuan, daftar bahan, urutan tahapan pelaksanaan, pengamatan, dan simpulan. Dalam hal menulis teks prosedur, siswa menuliskan hal yang benar-benar dialami oleh siswa 
dalam kehidupan sehari-hari di lingkungan sekolah. Misalnya dengan memasang dasi.

Dengan demikian, diharapkan guru bahasa Indonesia selalu memotivasi dan memberikan dorongan kepada siswanya agar dapat meningkatkan kemampuan menulis teks prosedur maupun pada materi yang lain. Kemudian, guru benar-benar juga dapat menjadi fasilitator yang baik dan memberikan penghargaan kepada seluruh siswa baik dalam bentuk penghargaan lisan maupun penghargaan dalam bentuk kinesik.

\section{KESIMPULAN DAN SARAN}

Berdasarkan hasil penelitian dan pembahasan dapat disimpulkan bahwa terdapat hubungan yang positif dan signifikan antara minat baca dengan kemampuan menulis teks prosedur pada siswa kelas VII SMP Negeri Sumber Rejo Kabupaten Musi Rawas. Hal ini dibuktikan dengan koefisien korelasi pada sebesar 0,01 lebih kecil dari 0,05 pada taraf signifikan 5\%, jadi Ha diterima. Hal ini membuktikan bahwa pada taraf signifikan $\alpha=0,05$ atau pada taraf kepercayaan $95 \%$ terdapat hubungan yang signifikan antara minat baca dan kemampuan menulis teks prosedur kompleks pada SMP Negeri Sumber Rejo Kabupaten Musi Rawas.

Beberapa saran dari hasil penelitian ini, yaitu: 1) bagi pihak sekolah atau bagi guru hendaknya mendorong siswa untuk meningkatkan minat baca untuk mencapai prestasi belajar yang lebih baik lagi. Hal itu bisa dilakukan agar siswa lebih semangat dan berprestasi. 2) Bagi dinas pendidikan, sebaiknya guru lebih diberikan pelatihan tentang metode pembelajaran yang mutakhir atau terbarukan sehingga mampu mengatasi permasalahan dalam pembelajaran menulis dan meningkatkan minat baca siswa. 3) Bagi orang tua diharapkan dapat menciptakan lingkungan belajar yang nyaman agar putra putrinya mempunyai minat membaca yang baik dan bisa konsentrasi dalam belajar. 4) Bagi siswa hendaknya dapat meningkatkan minat dalam belajarnya agar dapat mencapai prestasi belajar yang lebih baik lagi. Kemudian, 5) Peneliti lanjutan, penelitian ini hanya sebatas memberikan tingkat hubungan antara minat baca terhadap kemampuan menulis teks prosedur. Peneliti berikutnya bisa meneliti dengan desain penelitian lain seperti anava atau anakova.

\section{DAFTAR PUSTAKA}

Fitri, R. (2015). Kontribusi Minat Baca dan Penguasaan Kosakata terhadap Kemampuan Membaca Pemahaman Siswa Kelas X SMA Negeri 1 Padang Ganting Kabupaten Tanah Datar. Gramatika STKIP PGRI Sumatera Barat, 1(2). doi:10.22202/jg.2015.v1i2.1233

Mahsun. (2014). Teks dalam Pembelajaran Bahasa Indonesia Kurikulum 2013. Jakarta: Raja Grafindo Persada.

Noermanzah, N., Abid, S., \& Septaria, S. (2018). Improving the Ability of Writing a Narrative Charge by Using Animated Images Media Student Class V.B SD Negeri 17 Lubuklinggau. BAHTERA: Jurnal Pendidikan Bahasa dan Sastra, 17(2), 116. doi:10.21009/bahtera.172.9 
Korelasi antara Minat Baca dengan Kemampuan Menulis Teks Prosedur ...

Nurgiyantoro, B. (2012). Penilaian Pembelajaran Bahasa Berbasis Kompetensi. Yogyakarta: BPFE.

Permendikbud Nomor 24 Tahun 2016 tentang Kompetensi Inti dan Kompetensi Dasar.

Permendikbud Nomor 64 tahun 2013 tentang Standar Isi Pendidikan Dasar Dan Menengah.

Rusmini. (2018). Kemampuan Menulis Teks Prosedur Siswa Kelas VIII SMP Negeri 1 Kabupaten Pangkap. Skripsi, Fakultas Bahasa dan Sastra. Universitas Negeri Makasar.

Rustam, A. (2015). Dasar-Dasar Statistik. Kolaka: Putri Yolanda.

Sandjaja, S. (2005). Pengaruh Keterlibatan Orang Tua terhadap Minat Membaca Anak Ditinjau dari Pendekatan Stress Lingkungan, (Online), (http://www.pdfqueen.com, diakses tanggal 12 Januari 2019)

Soedarso. (1989). Sistem Membaca Cepat dan Efektif. Jakarta: PT Gramedia.

Somadayo, S. (2011). Strategi dan Teknik Pembelajaran Membaca. Yogyakarta: Graha Ilmu.

Susetyo. (2010). Guru Bahasa dan Sastra Indonesia yang Profesional. Bengkulu: FKIP.

Tampubolon. (1993). Mengembangkan Minat dan Kebiasaan Membaca pada Anak. Bandung: Angkasa. 